\title{
Chicago Center for Film Study
}

By Ron Holloway

Spring 2006 Issue of KINEMA

\section{CHICAGO CENTER FOR FILM STUDY: ORIGIN AND HISTORY}

One day in August, I was sitting in a restaurant during the Montreal World Film Festival when Jim Wall, the long-time editor, now retired, of the Christian Century, asked me about the origin and history of the Chicago Center for Film Study.

And would I put down my recollections of how it all began.

"Ask me an easier question" - was my immediate response.

After all, the story of the Center for Film Study (CFS) goes back forty years or more. To unravel all the salient facts and many colourful details would require access to the archives of the Adult Education Centers (AEC) in Chicago, the Catholic umbrella organization that nourished the growth of the CFS. And I am not sure those archives even exist.

Still, this is the place to start.

Back in the August of 1962, three years after my ordination to the priesthood, I was attending an OCIC (International Catholic Office for Cinema) conference in Montreal together with Monsignor Daniel Cantwell, chaplain and mentor of the AEC, and Dr. Russell Barta, its programming director. In the middle of the conference Dan Cantwell handed me a telegram from the Chancery Office.

Would I be willing to work one day a week at the AEC to help found a center for film study?

Of course, I jumped at the opportunity.

Parish work at St. Celestine in Elmwood Park was fine, but I was already a full blown cineaste who spent as much time as possible buried in books and journals about the history of the cinema. As a matter of fact, my Master of Arts degree at St. Mary of the Lake Seminary in Mundelein was on "The Positive Approach to the Cinema" - meaning, in my opinion, that the Catholic-sponsored Legion of Decency had to go.

Why not just reform it from the inside out? suggested Dan Cantwell.

And Russ Barta countered with a name for the new office: the Chicago Center for Film Study.

So that in a nutshell is how it started.

That's also when Henry Herx entered the picture.

Later, Henry was to become the key figure at the Catholic Office for Media and Broadcasting in New York.

But in the 1960s he made the CFS what it was to be for an exciting decade - a major center in the United States for the study of the seventh art.

At that time, Henry was the Assistant Principal at Lafayette Grammar School on the west side of Chicago. But, in my book, he was much more than that.

Henry was a walking encyclopaedia of the cinema.

He was also my school chum at Quigley Preparatory Seminary on the near north side of Chicago. As a matter of fact, our desks were alphabetically right next to each other: Herx and Holloway. Given circumstances like that, something had to rub off.

After school, back in those heady postwar years, we would do our homework across the street at Lewis Tower, the adjunct of Loyola University.

Then we would head for the nearby art houses to catch the $6 \mathrm{pm}$ show. 
The Cinema on Chicago Avenue. The Surf and the Carnegie near Bughouse Square. The Esquire on Oak Street. The World Playhouse on Michigan Avenue. The Clark in the Loop, with its double-bill of the classics.

In short, an invaluable after-school education that moulded my thinking for a lifetime.

As time passed, we would meet at any one of a dozen active film societies in the Chicago area. By this time, in the early 1960s, Henry was a teacher employed by the Chicago Board of Education, while I was now a Catholic priest (class of 1959) ordained for the Archdiocese of Chicago.

One day, at the urging of Vaile Scott at the AEC, I asked Henry if he would be free in the summer to work at the newly founded CFS. Also, I asked if he would help me program a film society in the auditorium at De Paul University in downtown Chicago.

That's when the Chicago Center for Film Study really got off the ground.

We presented Carl Theodor Dreyer's The Passion of Joan of Arc at De Paul with live music - the organ in the auditorium. And we had an overflow house for a feature-length cartoon - George Orwell's Animal Farm.

We also challenged the Legion of Decency by showing My Little Chickadee with W. C. Fields and Mae West. Sure enough, a letter of protest was sent to De Paul asking how a Catholic University could tolerate the screening of a "C" (for condemned) rated movie. We answered back that Fellini's La Strada, another C-rated film, had received an OCIC Jury Award at a European film festival.

About this time, I was asked by an editor at The New World, the Archdiocesan newspaper, to pen some reviews of newly released films. As you would expect, when my review of Tom Jones appeared in print, the CFS was getting some mean phone calls.

Never mind, though. Those few angry calls didn't even compare with the bitter telephone assaults experienced by the staff at the Catholic Interracial Council, the office next door to the AEC. The CIC was sponsoring the Bogen Marches in a Chicago neighbourhood on the south side and were encouraging trips to Selma, Alabama, to help with voter registration for blacks. A priest friend, Bill Morrisroe, got shot in the back for joining the Selma Marches.

Besides, said Dan Cantwell, the Chicago Center for Film Study was already recognized by the mid-1960s as one of the key research and publication centres on cinema in the United States.

Even Monsignor Thomas Little and Father Patrick Sullivan, SJ, at the Legion of Decency office in New York, were interested. We became the official Catholic office in the United States for promoting the positive approach to the cinema. Our status was upped to the National Center for Film Study. Henry Herx, finally, had a full-time job at the AEC.

Our work at the CFS was mostly publications - like newsletters, film notes, film reviews. But, on occasion, we conducted seminars, lectures, conferences, and whatever else fit the time and occasion. And, of course, the AEC offered its public a broad range of film courses at its centres around the city.

At this time, in the early 1960s, the Chicago Censorship Board was still active. It was the last of the city censorship boards, with a committee to handle appeals from distraught producers and distributors.

I did some research, conducted some interviews, and wrote an article in a liberal Catholic journal about "The Last of the City Censorship Boards" from the viewpoint of the CFS.

Mark Slade, head of the educational department at the National Film Board of Canada, invited me to Montreal to lecture at a conference on the general topic of film censorship.

I felt I was back home again.

The 1960s saw the heyday of the Adult Education Centers and the Center for Film Study.

After all, the Second Vatican Council had opened the doors to multiple forms of religious expressions. From the vernacular in religious services to ecumenical dialogue. From the philosophical questions posed by Jesuit 
paleontologist Teilhard de Chardin to "God Is Dead" theology in the films of Ingmar Bergman.

The AEC embraced all these challenges with open arms. Indeed, enrollment in the centres scattered across the city - in schools and universities, inside parish church halls, at assorted cultural institutions - was booming.

Programming was usually done by Russ Barta and Vaile Scott. Coordination and publicity were handled by Ann Coe and Lou Marrone. Henry Herx and I ran the De Paul film program, together with John Taylor (not to be confused with another John Taylor at the World Council of Churches) in the De Paul Media and Broadcasting Department.

Film study was also in. Our film notes at CFS were in demand. Offers to lecture came from across the country. On one occasion, I was invited by Al Milgrom, head of the Film Society at the University of Minnesota, to lecture on Buñuel's Viridiana at the local Newman Club. "The usual full house," said Al, when we walked into a crowded auditorium. "It happens whenever we show a Buñuel film."

Nearly all of Chicago's numerous film societies (I once counted 16 in a Daily News listing) fed off the 16mm film libraries at Audio, Brandon, Contemporary, Films Inc, and others. Now, with a dozen colleges and high schools running courses on film education, the $16 \mathrm{~mm}$ market was a goldmine for art film distributors. At some colleges you could even get credits for attending film seminars.

We knew at AEC that the staff at CFS had to be increased to meet the demand.

But how?

It happened in ways that puzzle me even today.

Ruth Parrington, head of the Film Rental Service at the Chicago Public Library, volunteered her programming services. She knew the animation and short film market like the back of her hand.

Paul Carrico, a Marist priest, founded the Screen Educators Society to enable film teachers in high schools to exchange ideas and programs via the auspices of the CFS. Paul later went on to study for a Doctorate in Film at Fordham University in New York.

Anthony (alias Peter) Schillaci, a Dominican priest stationed in River Forest, wrote copious film notes for the CFS. He went on to publish film study manuals and write erudite articles on the cinema, eventually leaving the Dominican Order to marry and reside in New York.

Gene Phillips, a Jesuit professor of English Literature at Loyola University in Chicago, was given carte blanche by his superiors to work in the field of Film and Theology. He later published a book on the cinema of Graham Greene.

Millie Purwin at the Contemporary Films office in Evanston, a treasure trove of quality short films, collaborated with me on a guide for the use of its catalogue by screen educators.

I can't even begin to name the nuns and teachers who contributed significantly to the success of the Chicago Center for Film Study. Let these few words stand as a mute gesture of profound thanks.

As the CFS grew, Henry Herx and I were invited to OCIC conferences and international film festivals. OCIC had a way of tying them both together.

At Venice I met Robert Bérubé, a Sulpician stationed in Montreal. A man who appreciated the art of the cinema better than most critics, Robert could talk at length on the cinema of Dreyer and Bergman, Bresson and Buñuel, Fellini and Antonioni. He knew all their films by heart.

It was then that I got the feeling that I could write a doctoral dissertation of my own on the cinema of Carl Theodor Dreyer, Ingmar Bergman, and Robert Bresson.

It eventually was to happen.

The breakthrough for the Chicago Center for Film Study came in the mid-1960s. 
That's when the American Council on Education sponsored two conferences on Film Education as an acceptable discipline in Schools of Higher Education.

Henry Herx and I were both invited.

The first weekend conference was in New York during the New York Film Festival. I remember sitting quietly in a corner listening to how the film courses were run at New York University, at UCLA, at the University of Southern California, and at the University of Iowa, to name just the leaders in the field back then.

The second conference was at Dartmouth College in New Hampshire. And it changed my life.

By some stroke of fate, my room in the Residence Hall was right next to that of Pauline Kael, not yet the doyenne of American film criticism but well on her way with a book of her collected writings.

"Why don't we open both of our doors and hold a running party every night to see who will come," she said after the first dull session at the conference. "It will help to shake the dust off some of these old cronies!"

Within a couple hours on the first evening, the rooms were packed. The next evening, the crowd flowed out into the corridor. I tried my best to be witty and intelligent-looking - until Pauline turned to me and said over a glass of Wild Turkey: "Don't worry. Most of them here are fakes. Haven't you already noticed?"

It was the beginning of friendship that stretched over two decades.

Once, when a reporter at the Chicago Daily News wanted to do a feature story on Pauline, he phoned me to asked if it could be arranged. He had heard that I was picking her up at O'Hare Airport to drive her down to the University of Illinois in Urbana for a lecture.

"Why not," I responded rather brashly. "Provided you can invite her to a good restaurant. She's at her best in a one-on-one over dinner."

Grateful that I was asked to come along, I credit that evening for teaching me how to conduct an interview without a tape-recorder or even pencil-and-paper at your elbow. It's not what a person says, it's what he or she really believes in. Once that comes across, you've got your story.

Shortly thereafter, I was called by Michaela Williams at the Daily News to ask if she could stop by the office for an interview.

"Of course," I mumbled nervously. "But let's include Henry Herx too."

The upshot was a whole page in a Saturday edition devoted entirely to the Chicago Center for Film Study. And, wouldn't you know it, the one angle in the story that interested her the most was the question we really didn't want to answer.

"What's going to happen now to the Legion of Decency?"

That upbeat Daily News story led to another phone call.

This one came from Ronald Gold at Variety, asking when I would be in New York the next time. Since I was now commuting between Chicago and New York on a regular basis, I set a convenient date for both of us.

Ronald Gold, too, wanted to know if the Legion of Decency was on its way out. A question I simply could not answer, even if I knew and felt that its demise was already on the horizon. A National Catholic Office for Media and Broadcasting was in the works, to match our own National Center for Film Study.

A third interview was the straw that broke the camel's back.

Judy Stone, a reporter for the San Francisco Chronicle, was asked to write a feature story for a liberal Catholic journal called Ramparts. Since she wasn't having much luck with Monsignor Little at the Legion of Decency Office, would I be willing to give her some time on her trip through Chicago to New York? 
We met at a Screen Educators seminar held at the Illinois Institute of Technology, a place where clerics and nuns mingled with educators of all religions and backgrounds. On the agenda was a screening of a Jean Genet short.

In her story Judy Stone spiced the rendezvous with the Genet short. Nuns viewing a Genet film, if they wanted to take their chances, didn't bother me at all. We were already used to that kind of mixed crowd at film seminars.

It was the headline for the story that shook me a bit: Ramparts plugged her story as "The Lesion of Decency" - instead of "The Legion of Decency."

I knew my days were now numbered at the Archdiocese of Chicago.

After John XXIII came Paul VI. And the Second Vatican Council was history.

After the liberal Cardinal Meyer came the conservative Cardinal Cody. And the Adult Education Centres was also history.

Towards the end of the 1960s, Henry Herx packed his bag and went to New York to work at the newly established National Catholic Office for Media and Broadcasting. He became the "writer's backbone" of that restructured organization.

Henry also became a representative of the National Catholic Office for Media and Broadcasting to the appeal board set up by the Motion Picture Association of America to hear the arguments of producers with a gripe. Could a better rating be found for a controversial film that pushed the ethics of adult viewers to the limits? The appeal board was the court of last resort for the producers and directors.

Jim Wall, editor of the Christian Century in Chicago, has been, for many years, the Protestant representative to the appeal board, appointed to that position by the National Council of Churches. The ratings board and the appeals board is under the direction of the longtime MPAA president, Jack Valenti.

Meanwhile, I wrote a bunch of letters to friends I had made in that Residence Hall at Dartmouth. I was applying to the Rockefeller Foundation to write a book on "The Religious Dimension in the Cinema, with particular reference to the films of Carl Theodor Dreyer, Ingmar Bergman, and Robert Bresson."

In fact, at that time, the book was almost finished.

Later, thanks to John Taylor at the World Council of Churches, it was published under the title Beyond the Image.

It was originally meant to be my dissertation at the Institute Catholique in Paris. Along the lines of writings by Amédée Ayfre and his close friend André Bazin, the mentor of François Truffaut.

I had already spent a part of two summers in Paris, screening films at the Cinémathèque Française, courtesy of Henri Langlois. And helping during the day with odd jobs about the office.

Anyway, I received a two-year Rockefeller Grant. Better still, as a Rockefeller Fellow, I was allowed to go to Paris to live and write.

So what happened to the Chicago (aka National) Center for Film Study?

Better ask Jim Wall.

Over the years, probably out of the same passionate conviction that marked the beginning, he has kept it alive and well.

Registered under a copyright title.

Thanks, Jim.

Because those seven years were the most rewarding of my life. 


\section{Author Information}

Ron HOLLOWAY (1933-2009) was an American critic, film historian, filmmaker and correspondent who adopted Europe as his home in the early fifties and spent much of his life in Berlin. He was an expert on the study of German cinema and against all odds produced, with his wife Dorothea, the journal German Film, keeping us up-to-date with the work of directors, producers and writers and the showing of German films around the world.

In 2007, Ron Holloway and his wife were awarded the Berlinale Camera Award. Ron also received the Bundesverdienstkreuz (German Cross of Merit), Polish Rings, Cannes Gold Medaille, the American Cinema Foundation Award, the Diploma for Support of Russian Cinema and an honorary award from the German Film Critics' Association.

Ron was also a valued contributor to Kinema for the past fifteen years. 